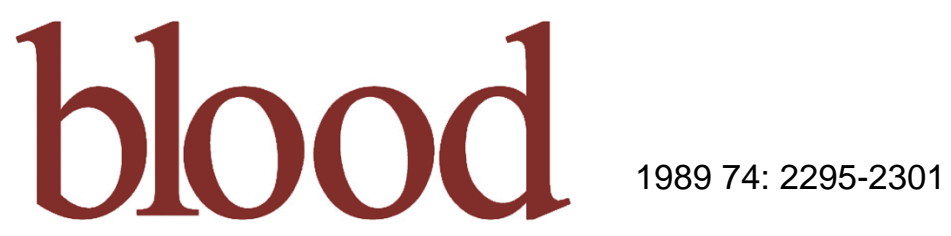

\title{
Detection of HIV-1-infected cells from patients using nonisotopic in situ hybridization
}

RH Singer, KS Byron, JB Lawrence and JL Sullivan

Information about reproducing this article in parts or in its entirety may be found online at: http://bloodjournal.hematologylibrary.org/misc/rights.dtl\#repub_requests

Information about ordering reprints may be found online at:

http://bloodjournal.hematologylibrary.org/misc/rights.dtl\#reprints

Information about subscriptions and ASH membership may be found online at: http://bloodjournal.hematologylibrary.org/subscriptions/index.dtl

Blood (print ISSN 0006-4971, online ISSN 1528-0020), is published semimonthly by the American Society of Hematology, 1900 M St, NW, Suite 200, Washington DC 20036.

Copyright 2007 by The American Society of Hematology; all rights reserved.

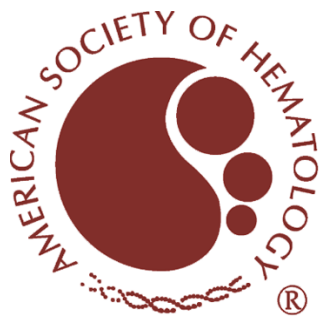




\title{
Detection of HIV-1-Infected Cells From Patients Using Nonisotopic In Situ Hybridization
}

\author{
By Robert H. Singer, Kevin S. Byron, Jeanne B. Lawrence, and John L. Sullivan
}

\begin{abstract}
We have demonstrated that a sensitive, nonisotopic in situ hybridization (ISH) assay can be used to detect HIVinfected cells from seropositive, asymptomatic individuals. Our assay is based on the detection of a biotinated HIV DNA probe hybridized to human immunodeficiency virus (HIV)-infected peripheral blood lymphocytes (PBL) using streptavidin and alkaline phosphatase to identify positive cells. This assay is rapid in that it can be performed within a day and is sensitive enough to unambiguously identify a rare, single, positive cell. Patient samples derived from HIV-seropositive hemophiliacs and HIV-seropositive infants were analyzed before and after coculture with normal PBL. The same samples were investigated using a Dupont
\end{abstract}

$\mathbf{A}^{\mathrm{c}}$ CQUIRED immunodeficiency syndrome (AIDS) has affected over 60,000 individuals in the United States over the past 10 years with a mortality rate of approximately $60 \%$.' Based on surveys of seroprevalence, it has been estimated that 1 million to 1.5 million Americans have been infected with the human immunodeficiency virus type I (HIV 1). ${ }^{2}$ Little information is currently available regarding the direct detection and quantitation of HIV infection in vivo. It is known that blood, semen, and vaginal secretions harbor HIV and represent the sources of spread of HIV from infected to noninfected individuals. Once HIV enters the host, the virus infects and replicates in a variety of cells, including blood and tissue monocytes/macrophages and T-helper (CD4) lymphocytes. ${ }^{3}$ Viral replication precedes the production of antibody by the host and may occur in the absence of symptoms. The recent studies of Ward et $\mathrm{al}^{4}$ suggest that as many as 460 individuals/year are infected with HIV because of HIV-contaminated blood products. These HIV-infected blood products are obtained from seronegative donors who are thought to be acutely HIV infected and viremic prior to the appearance of HIV antibody. While the risk of acquiring HIV infection through blood transfusion remains low ( 1 in 40,000 ), it is probable that continual spread in the heterosexual community will result in more blood donors being in the "window period" of HIV infection. The development of a rapid, sensitive, and convenient nonradioisotopic in situ hybridization assay to detect the viral genome directly in infected cells would increase the likelihood of detecting all HIV-infected individuals prior to the generation of a virus-specific immune response. A method to detect HIV directly would also be extremely useful in those situations when antibodies are not informative $(\mathrm{eg}$, in infants of HIV-seropositive mothers where passively acquired maternal antibodies obscure the diagnosis ${ }^{5}$ and in those HIV-infected individuals who fail to mount an appropriate antibody response ${ }^{6}$ or lose the ability to maintain HIVspecific antibody following acute infection. ${ }^{7}$ Finally, a sensitive and quantitative method of detecting HIV-infected cells would be helpful in assessing the natural history of infection and in monitoring antiviral therapy or vaccine development.

In situ hybridization offers distinct advantages over immunlogic methods, since it is able to detect infected cells whether or not viral proteins are expressed. Such hybridiza-
P24 antigen-capture kit. It was found that ISH always detected the same positive samples as antigen capture, often in shorter times of coculture. In situ hybridization detected over half of our HIV-infected hemophilia patient population as virus positive, whereas the antigen capture assay detected less than one fourth as virus positive. In situ hybridization detected positive cells directly, without coculture, in 12 out of 35 (34\%) hemophiliacs and in three out of eight (37\%) infants. The speed, sensitivity, and confidence of ISH and nonisotopic detection indicates that it will be useful as a tool for clinical research and diagnosis.

- 1989 by Grune \& Stratton, Inc.

tion was first used to detect HIV-infected cells in frozen brain tissue obtained from AIDS patients. ${ }^{8}$ Harper et al ${ }^{9}$ have published a further report demonstrating the detection of HIV-infected cells in the lymph nodes and peripheral blood of individuals with AIDS and AIDS-related complex (ARC) by in situ hybridization. Bush et $\mathrm{al}^{10}$ have shown that in situ hybridization can be used to detect virus-positive cells in cocultures of peripheral blood mononuclear cells from symptomatic patients at an earlier time of culture compared to any other viral detection technique. In these reports the in situ hybridization methodology" employed a radioisotopically $\left({ }^{35} \mathrm{~S}\right)$ labeled probe. This report improves and applies nonisotopic in situ hybridization (ISH) to the detection of HIV-infected cells

\section{METHODS}

Preparation of peripheral-blood lymphocytes and coculture. Blood was obtained by venous puncture and the lymphocytes separated by Ficoll-Hypaque (FH) centrifugation. Peripheral blood mononuclear cells were isolated from seronegative and seropositive individuals $\left(3 \times 10^{6}\right.$ cells $)$ and cocultured with cells $\left(3 \times 10^{6}\right)$ from healthy seronegative donors that had been stimulated for 3 to 4 days with phytohemagglutinin (PHA) $(2 \mu \mathrm{g} / \mathrm{mL}$, Wellcome Diagnostics, Research Triangle Park, NC). Cocultured cells were maintained in HEPES-buffered RPMI 1640 supplemented with 20\% fetal calf serum (FCS), $2 \mu \mathrm{g} / \mathrm{mL}$ polybrene (Sigma Diagnostics, St Louis,

From the Departments of Cell Biology, Pediatrics, Molecular Genetics and Microbiology. University of Massachusetts Medical School, Worcester, MA.

Submitted March 1, 1989; accepted July 5, 1989.

Supported by a contract from the NHLBI, National Institutes of Health (NIH)HB-67027 to R.H.S. and J.L.S.; and NIH grants HD 18066 to R.H.S. and J.B.L., HL 42257 to J.L.S. J.L.S. is an established Investigator of the American Heart Association.

Address reprint requests to Robert $H$. Singer, PhD, Department of Cell Biology. University of Massachusetts Medical School, 55 Lake Ave N, Worcester, MA 01655.

The publication costs of this article were defrayed in part by page charge payment. This article must therefore be hereby marked "advertisement" in accordance with 18 U.S.C. section 1734 solely to indicate this fact.

(c) 1989 by Grune \& Stratton, Inc.

0006-4971/89/7406-0060\$3.00/0 
MO), 10\% interleukin-2 (IL-2, Cellular Products Inc, Buffalo, NY), and $12.5 \mu \mathrm{g} / \mathrm{mL}$ gentamicin (GIBCO, Grand Island, NY) for 3 weeks. Cultures were split twice weekly and were supplemented with fresh PHA-stimulated normal mononuclear cells at 7-day intervals.

Immunofluorescence. Cells were mixed with a 1:100 dilution of patient serum (from a HIV-seropositive individual) in phosphatebuffered saline (PBS) and, after a series of washes in PBS, were detected with fluorescein-conjugated rabbit antihuman IgG (Cappel Laboratories, Organon Teknika, West Chester, PA). Cells were visualized under epifluorescence optics at $40 \mathrm{X}$ objective.

Dot blot. Cellular pellets $\left(2 \times 10^{6}\right.$ cells $)$ were washed and extracted three times with phenol chloroform after sodium dodecyl sulfate (SDS) (1\%) treatment of the cells. Isolated nucleic acids were purified by ethanol precipitation, resuspended in high salt $(0.3$ $\mathrm{mol} / \mathrm{L} \mathrm{Na}$ acetate), and blotted onto nitrocellulose filters. Filters were hybridized with ${ }^{32}$ P-labeled HIV genomic probe ${ }^{12}\left(3 \times 10^{8}\right.$ $\mathrm{cpm} / \mu \mathrm{g}$ ) overnight, washed, and exposed for 72 hours to radiographic film with intensifying screens.

Probe preparation by nick translation. An amount of $1.5 \mu \mathrm{L}$ of $400 \mu \mathrm{mol} / \mathrm{L}$ biotin dUTP ${ }^{13}$ (BRL, Gaithersburg, MD) or the corresponding dATG mix for radioactive probes (or for radioactive probes, 35S-dCTP, Amersham 1,000 Ci/mmol/L, diluted 1:3 with unlabeled dCTP and used at a final concentration of $6 \mu \mathrm{mol} / \mathrm{L}$ ), 1 $\mu \mathrm{L}$ of dACG mix (dATP, dCTP, dGTP $600 \mu \mathrm{mol} / \mathrm{L}$ each, PL Biochemicals, St Louis, MO), or dAGT mix for radioactive probes, 1 $\mu \mathrm{L}$ of $10 \mathrm{X}$ nick translation buffer $(0.5 \mathrm{~mol} / \mathrm{L}$ Tris $\mathrm{Cl}, \mathrm{pH} 7.2 ; 0.1$ $\mathrm{mmol} / \mathrm{L} \mathrm{MgSO}_{4} ; 1 \mathrm{mmol} / \mathrm{L}$ dithiothreitol), $500 \mu \mathrm{g} / \mathrm{mL}$ bovine serum albumin (BSA, Pentax Frac V) $5-\mu \mathrm{L}$ sterile glass distilled $\mathrm{H}_{2} \mathrm{O} ; 1 \mu \mathrm{L}$ of $0.1 \mu \mathrm{g} / \mu \mathrm{L}$ HIV DNA (pJM [HIV-1]8.9[12] containing $8.9 \mathrm{~kb}$ of HIV-1 DNA), $1 \mu \mathrm{L}$ of DNase (final $34 \mathrm{ng} / \mathrm{mL}$ : concentration determines the probe size; large probe sizes cause background), $1 \mu \mathrm{L}$ of DNA Polymerase I (Boehringer). Incubation is 3 hours at $15^{\circ} \mathrm{C}$, then $90 \mu \mathrm{L}$ of $50 \mathrm{mmol} / \mathrm{L}$ EDTA and $1 \mu \mathrm{L}$ of $10 \%$ SDS is added. Purification from incorporated nucleotides is with a sterile G50 sephadex "spin" column packed in a $1 \mathrm{~mL}$ disposable syringe.

In situ hybridization. The schematic in Fig 1 outlines the following methodology. Cells were washed in PBS, and $25 \times 10^{5}$ cells in $25 \mu \mathrm{L}$ were applied to each well of a multiwell serologic slide (Celline, 5-mm wells). The excess fluid was immediately withdrawn by the pipette, leaving cells to be air dried (10 minutes), fixed in $4 \%$ paraformaldehyde in PBS ( 5 minutes), and stored in $70 \%$ ethanol at $4^{\circ} \mathrm{C}$. From $1 \%$ to $4 \%(25,000$ to 100,000 ; median 50,000$)$ of the cells applied actually remain adhered to the slide. At appropriate times, slides stored in $70 \%$ alcohol are rehydrated in a 10-minute PBS, 5 $\mathrm{mmol} / \mathrm{L} \mathrm{MgCl}$ bath, then 10 minutes in $0.5 \%$ triton/0.5\% saponin solution, washed in $2 X \mathrm{XSC}$, treated for 10 minutes in $0.1 \mathrm{~mol} / \mathrm{L}$ triethanolamine and $0.25 \%$ acetic anhydride, washed again in $2 \mathrm{X}$ SSC, and incubated for 2 minutes at $70^{\circ} \mathrm{C}$ in $70 \%$ formamide in $2 \mathrm{X}$ SSC before plunging into $70 \%$ ethanol and dehydrating through graded ethanol and air drying. This makes viral DNA as well as RNA accessible for hybridization. While the cells can be hybridized directly out of the $70 \%$ ethanol after rehydration in PBS, for a shorter pretreatment protocol, the signal is diminished. Forty nanograms of probe DNA is used, which can be obtained by aliquoting 40 $\mu \mathrm{L}$ of nick-translated probe into a microfuge tube and lyophilizing it with $4 \mu \mathrm{L}$ of carrier nucleic acids $(10 \mathrm{mg} / \mathrm{mL}$ of sheared salmon sperm and $t R N A)$. Five microliters of deionized formamide is mixed with the lypholite and placed in a $90^{\circ} \mathrm{C}$ heating block for 10 minutes. Hybridization buffer is prepared by mixing $30 \mu \mathrm{L} 20 \mathrm{XSC} ; 30 \mu \mathrm{L}$ BSA, $60 \mu \mathrm{L}$ dextran sulfate ( $50 \%$ solution, autoclaved in water) and $30 \mu \mathrm{L} \mathrm{H}_{2} \mathrm{O}$. Slides are then quickly used with the deposition of $5 \mu \mathrm{L}$ of the heated probe mixed rapidly with an equal amount of hybridization buffer onto each serologic well ( $10 \mu \mathrm{L}$ total), covered with a small strip of parafilm, and placed for 3 hours (or overnight as is

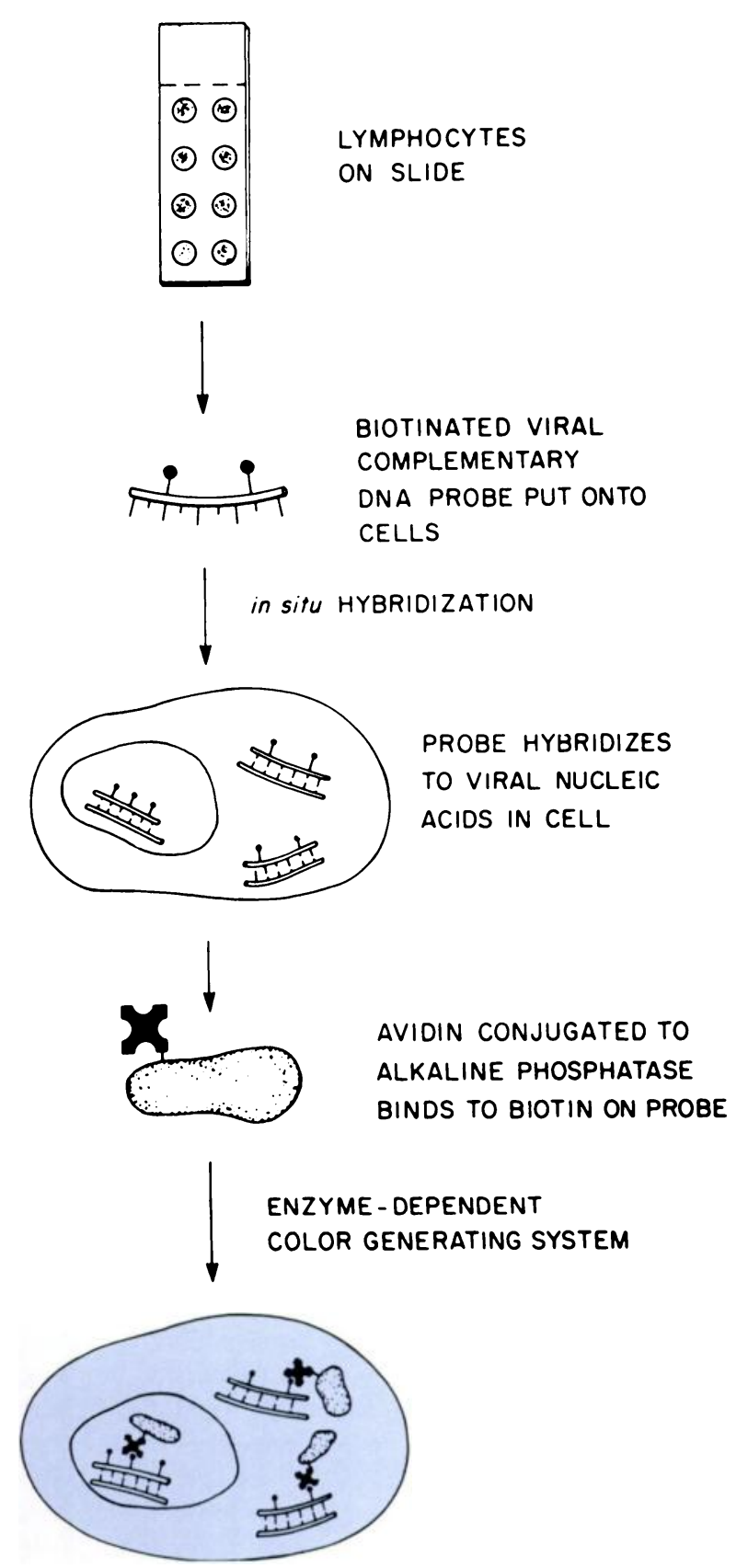

Fig 1. Schematic of the nonisotopic in situ hybridization and detection protocol.

convenient) in a humidified $37^{\circ} \mathrm{C}$ incubator. Slides are rinsed in $50 \%$ formamide in $2 \mathrm{X} \mathrm{SSC}$ for 30 minutes at $37^{\circ} \mathrm{C}$, then placed in $2 \mathrm{X}$ SSC for 30 minutes and finally in $1 X$ SSC for 30 minutes.

Probes obtained from Molecular Biosystems, Inc (Dupont SNAP probe, San Diego, CA) were used at a concentration of $1 \mathrm{ng}$ per hybridization $(6 \mathrm{nmol} / \mathrm{L}$ concentration). Cells were hybridized in 5X SSC, $0.5 \%$ SDS, and $1 \% \mathrm{BSA}$ at $50^{\circ} \mathrm{C}$ for 20 minutes in a humidified environment. Samples were then washed at $42^{\circ} \mathrm{C}$ for 5 minutes in $1 \mathrm{X} \mathrm{SSC}$ at room temperature for 5 minutes each. The detection of the alkaline phosphatase was as described below.

Detection of biotinated probes. Originally streptavidin followed by biotinated alkaline phosphatase after the method of Singer et $\mathrm{al}^{14}$ 
Table 1. Detection of HIV-Infected Cells From Seropositive and Seronegative Individuals: Comparison of Antigen-Capture ELISA With In Situ Hybridization

\begin{tabular}{llc}
\hline \multicolumn{1}{c}{ Patient Population (N) } & $\begin{array}{c}\text { p24 Antigen Capture } \\
\text { Positive (\%) }\end{array}$ & $\begin{array}{c}\text { In Situ } \\
\text { Hytridization } \\
\text { Positive (\%) }\end{array}$ \\
\hline Coculture* & & \\
Seronegative hemophiliacs (2) & 0 & 0 \\
Seropositive hemophiliacs (34) & $8(24 \%)$ & $18(54 \%)$ \\
Seronegative normal controls (8) & 0 & 0 \\
Seropositive infants (15) & $5(33 \%)$ & $8(53 \%)$ \\
Direct detection* & & 0 \\
Seronegative normal controls (7) & 0 & $12(34 \%)$ \\
Seropositive hemophiliacs (35) & $4(11 \%)$ & $3(37 \%)$ \\
Seropositive infants (8) & $2(25 \%) \dagger$ & \\
\hline
\end{tabular}

- At four intervals over 21 days, the culture was tested, and the sample was considered positive if any one of those days was positive. For in situ hybridization, 1 cell per well (average 50,000 cells) was sufficient for a positive determination. For the P24 antigen capture ELISA, the samples were assayed as described by Dupont: $200 \mu \mathrm{L}$ of supernatant was tested, and readings corresponding to $40 \mathrm{pg} / \mathrm{mL}$ of p24 antigen or greater were considered positive. For direct detection, patient mononuclear cells were put directly on slides and processed as described previously. Serum samples were tested for the presence of p24 antigen on each patient studied by direct detection.

†Both infants with detectable serum p24 antigen had symptomatic HIV infection, one each with AIDS and progressive generalized lymphadenopathy. was used for the data presented in Figs 2 and 3. The clinical results reported in Table 1 were obtained using streptavidin-alkaline phosphatase conjugate (Dakopatts, Santa Barbara, CA), which removes a step in the detection protocol and improves the background. The conjugate is used after dilution $1: 250$ into $4 \mathrm{XSSC}$ with $1 \% \mathrm{BSA}$ and exposed to the hybridized cells for 30 minutes. After washing in $4 \mathrm{X}$ SSC (three washes for 10 minutes each), the cells were put into a pH 9.5 solution $\left(0.1 \mathrm{~mol} / \mathrm{L}\right.$ Tris, $0.1 \mathrm{~mol} / \mathrm{L} \mathrm{Nacl}, 50 \mathrm{mmol} / \mathrm{L} \mathrm{MgCl}_{2}$ ) for color development with nitroblue tetrazolium (BRL, Gaithersburg, MD; 1:230 dilution) and bromochloroindolyl phosphate (BRL, Gaithersburg, MD;1:300 dilution; developed 20 to 30 minutes). Isotopic detection was by standard autoradiographic technique; development was for 3 to 5 days.

\section{RESULTS AND DISCUSSION}

In this work we describe the application of in situ hybridization followed by enzymatic, nonisotopic detection ${ }^{14-16}$ to the detection of HIV in a variety of cellular samples. Since the report of Harper et al, ${ }^{9}$ it was apparent that the application of the approach to HIV detection in clinical samples required that it be sensitive, convenient, and yet permit a signal to be evident in an extremely rare infected cell with no background contributed by negative cells. A progressive approach to the improvement of methodologies for rapid in situ hybridization and detection was used. Initial experiments used the producer lines of HIV (CEM or H9) in which a majority of cells are highly positive to optimize protocol conditions. For instance, conditions that provided optimal retention of cells on slides were monitored by microscopy. Fixation of the cells, treatments prior to probe application,
Fig 2. Detection of serially diluted infected cells: in situ hybridization versus dot blot or immunofluorescence. CEM cells chronically infected with HIV were serially diluted 1:1 with uninfected CEM cells, and aliquots were taken for microscopy. Methods of detection used an indirect immufiuorescence assay and in situ hybridization. In addition, dot blots were made from RNA isolated from aliquots of the same cells. (A) Dilution curve (O-O): percent infected cells (average of 10 fields). ( $\square-\square$ ) Identical samples measured by immunofiuorescence. $(X-X)$ The expected percent of infected cells determined by calculation at each dilution. Since the undiluted sample contained $7 \%$ positive cells, as determined by in situ hybridization, this provided the numerator in the serial dilutions. (B) Samples in (A) taken for dot-blot analysis.

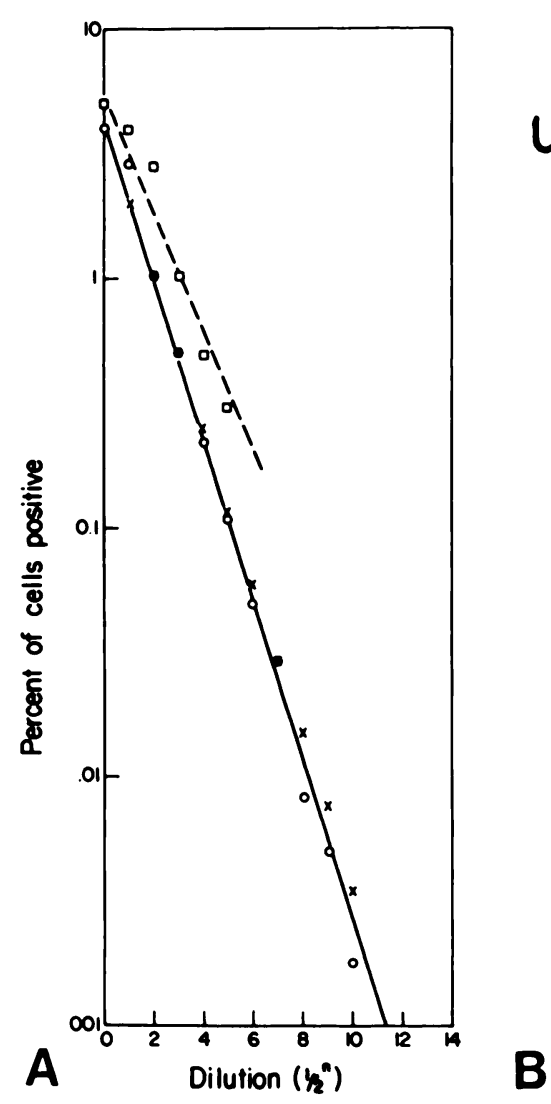




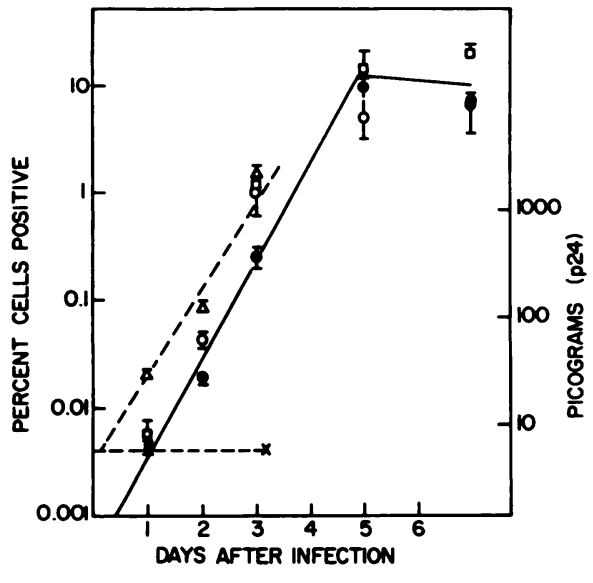

Fig 3. Kinetics of infection of normal T lymphocytes: Detection of infected cells by in situ hybridization of antigen capture. Normal T Iymphocytes were cultured in vitro for 3 days with IL-2 and PHA and than were infected with HIV-1 at low multiplicity of infection (MOI). At daily intervals, including just after exposure to the virus (day 0 ), cell samples were taken for in situ hybridization. Three methods of in situ hybridization were used: isotopically labeled probe (open squares), nonisotopically labeled probe (open circles), and conjugated oligonucleotides (0-). In addition, p24 was measured in the supernatant of the culture using an ELISA method (open triangles) (Dupont first-generation kit). Control, uninfected cells were processed at days 0,1 , and 3 for the ELISA assay for p24 $(x---x)$. For the in situ hybridization, the results were 0 cells positive on day 0 and day 3.

and hybridization conditions, all of which influence probe penetration ${ }^{11}$ and accessibility to the target molecules, were monitored by isotopic detection using $32 \mathrm{p}$-labeled probe followed by scintillation counting or detection nonisotopically. Finally nonisotopic detection was evaluated by variation in chromogen development time or conditions of streptavidin-alkaline phosphatase incubation and washing. After color development, quantitative data were obtained by counting the positive cells under the microscope and expressing them as a percent of total cells. Once the protocols for detection of HIV were established, comparison of in situ hybridization with conventional methods of virus detection such as RNA dot blot ${ }^{17}$ and antigen capture methods ${ }^{18}$ was possible. By providing information as to numbers of cells infected in situ, hybridization provides a means to evaluate sensitivity, where we have defined sensitivity as the ability to detect the rare cell. We evaluated this form of sensitivity by a mixing experiment in which positive cells were diluted (to less than one in $10^{5}$ cells). Virus-positive cells were serially diluted by uninfected cells and the percent positive cells at each dilution determined by in situ hybridization. Aliquots were also collected for dot-blot filter hybridization or the indirect immunofluorescence. Approximately $7 \%$ of the cells in the initial cell culture were positive ( 1 in 14 cells), and these positive cells could be accurately detected by nonisotopic in situ hybridization when diluted to one infected cell per 14,000 (Fig 2A). The false-positive rate was determined on an uninfected population of cells and was found to be zero (no false positives seen in 100,000 cells). Because of the visual requirements for characterizing a cell as positive (the cell must be completely colored, indicating significant amounts of viral RNA in the cytoplasm), the possibility of a cell being a false positive is negligible. In several million uninfected cells viewed over many months, we have never seen a cell that we would characterize as positive. With background levels this low, any signal is significant, and a single positive cell represents sufficient signal to score a sample as positive. This does not mean that samples are negative if no cell is seen, since a low level of positive cells may result in sampling variations that eliminate positive cells. A single positive cell could be detected with confidence in 50,000 negative cells in many of our samples.

On equivalent samples it was found that the limit of sensitivity of dot-blot filter hybridization of cellular DNA was equivalent to one infected cell per 900 (Fig 2B). The sensitivity of indirect immunofluorescence was limited due to the higher magnification required by epifluorescence and the tendency to identify weakly fluorescent cells as false positive. Hence, detection of infected cells by immunofluorescence was also accurate in our hands to only about one infected cell per 1,000 .

Another model to assess comparative sensitivity is to follow the infection of a culture with time where the amount of viral nucleic acids per cell is increasing, eventually to as many as tens of thousands of copies of HIV RNA per cell. ${ }^{19}$ Hence the increase in the number of detectable cells in a population should represent the increase in viral nucleic acid per cell as well as an increase in infected cells. Normal PHA-activated $T$ lymphocytes were infected with HIV (HTLV-III B) and sampled at daily intervals for 1 week for HIV detection by in situ hybridization or p24 antigen capture by ELISA assay (Dupont, Wilmington, DE). In situ hybridization was done using isotopically labeled probes detected by autoradiography, biotinylated probes detected by streptavidin and alkaline phosphatase, and oligonucleotide probes conjugated to alkaline phosphatase directly (SNAP probes) in a system where fewer copies of HIV per cell are expressed when compared with producer cell lines. Both the isotopic and nonisotopic detection of in situ hybrids using the nick-translated genomic probe were of comparable sensitivity (Fig 3). The mixture of three different enzymelinked oligonucleotides detected, on the average, $25 \%$ of the cells detected using nick-translated probes, and only after an overnight exposure to the chromagen. We have recently tested a mixture of 20 enzyme-linked oligonucleotides (kindly provided by MBI DuPont, Billerica, MA) and found that the time required for sufficient color development to detect the positive cells was decreased approximately proportional to the increase in the mixture complexity.

The antigen capture ELISA test was used on the same samples as in situ hybridization. It was found to be the less sensitive method as a result of background levels (about 5 $\mathrm{pg} / \mathrm{mL}$ ). Since results from both methods were determined on equivalent samples, it is possible from Fig 3 to determine how many positive cells (defined by in situ hybridization) are required for a positive determination by antigen capture ELISA assay. We used $40 \mathrm{pg} / \mathrm{mL}$ as a confident positive determination. This level of $\mathrm{p} 24$ expression would correspond to approximately 1 positive cell per 2500 negative cells. A lower limit of detection $(10 \mathrm{pg} / \mathrm{mL})$ would correspond to approximately 1 cell positive per 11000 (this value may be 
more compatible with the more sensitive tests now available from Abbott or DuPont). The background level for in situ hybridization in this experiment was not detectable (less than 1 cell per 100,000 uninfected cells). From these considerations there is an order of magnitude improvement in sensitivity in detecting cells actively undergoing viral replication when using in situ hybridization relative to the best available p 24 antigen-capture tests. It should be emphasized that these tests measure different parameters of infection. Antigen is detected in the supernatant of the cell cultures, presumably as a result of lytic infection. These cells would not be detected by in situ hybridization. Conversely, cells undergoing viral replication or expression would be detected by in situ hybridization but not necessarily by antigen capture. The direct measurement of virus-positive cells therefore becomes less comparable with the ELISA as antigen accumulates in the media with increasing time in culture. Therefore these two approaches should be seen as providing complementary information.

\section{APPLICATION TO CLINICAL SAMPLES}

If the in situ hybridization approach is to become useful clinically, it must be able to detect the rare virus-positive cells from infected individuals. ${ }^{9}$ To determine the ability of nonisotopic in situ hybridization to detect HIV in the blood of HIV-infected patients, we hybridized patient mononu- clear cells after coculture with normal, stimulated, human $T$ lymphocytes and also performed direct hybridization of patient mononuclear cells without coculture. As in the previous experiment, we compared all samples with results of the p24 antigen-capture assay. Two different HIV-seropositive patient populations were studied: one population consists of hemophiliacs who are seropositive but asymptomatic, the other of infants of seropositive mothers. Results are shown in Table 1 . In situ hybridization detected virus-positive cells in $53 \%$ to $54 \%$ of both groups during a 3-week coculture with normal, stimulated $\mathrm{T}$ lymphocytes. The $\mathrm{p} 24$ antigen-capture ELISA test detected $24 \%$ to $33 \%$ of these samples as positive, all of which agreed with the in situ hybridization results. Repeated samplings gave similar results. While in situ hybridization can detect positive cells with shorter times of culture, ${ }^{10}$ improvements in both viral culture as well as the p24 ELISA are also expected to decrease the time needed for coculture. The isolation of HIV from $98 \%$ of HIV seropositive hemophiliacs using an improved coculture technique with a larger inoculum $\left(10 \times 10^{6}\right)$ of patient mononuclear cells has been recently reported. ${ }^{20}$ Furthermore, both Dupont and Abbott have produced more sensitive p24 detection that allows decreased culture time. Preliminary comparisons on similar samples indicate that these improvements increase the percent of samples scored as positive. As described previously, in situ hybridization continues to provide quanti-
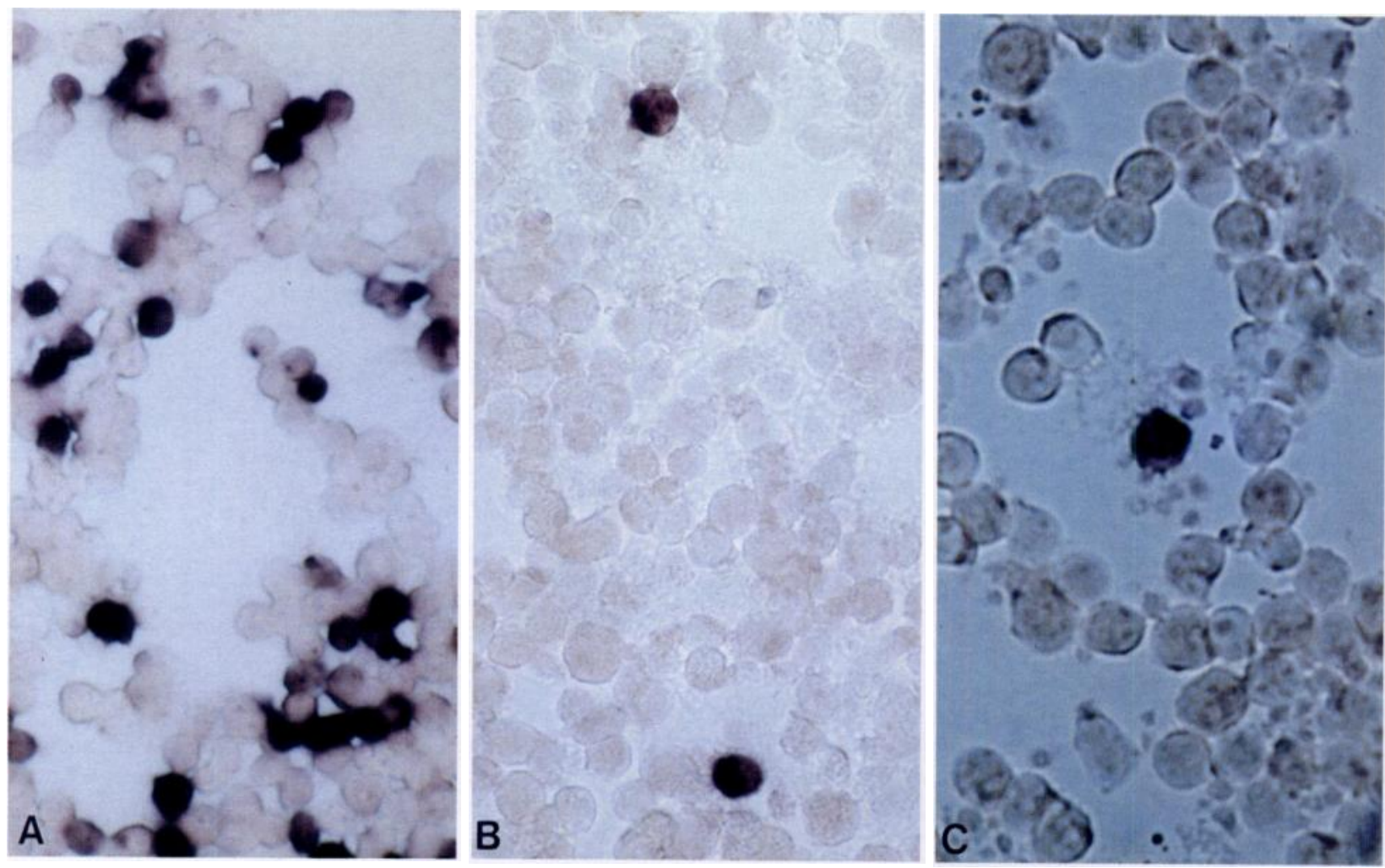

Fig 4. Examples of detection of viral nucleic acids in positive cells using in situ hybridization. (A) Cells from a normal lymphocyte culture were infected in vitro with HIV-1 and cultured for 7 days. At this point $16 \%$ of the cells were positive and were clearly distinguishable from the uninfected cells. (This constitutes a positive control slide used in conjunction with all our patient detections.) (B) Positive cells from a seropositive individual after a 7-day coculture with normal lymphocytes. Positive cells were $0.1 \%$ of total cells. (C) Direct detection of positive cells from patient similar to (B). Positive cells were $0.01 \%$ of total cells. (Note that phase microscopy increases the contrast of negative cells.) 
tative cellular information complementary to these other techniques.

The ability of in situ hybridization to detect rare, positive cells makes it immediately applicable to patient peripheralblood lymphocytes. Cells from the same adult patient population investigated with coculture above were tested directly without coculture. Approximately two thirds of the number of patients detected after coculture were detected positive without use of coculture (34\%). The number of virus-positive cells detected in these patients varied between 1 cell to 10 cells per well (average 50,000 cells/well). The antigencapture assay was positive on $11 \%$ of these patients' serum. The CD4-positive cells of these patients were also assessed, but no obvious correlation was found between CD4 lymphocytes and number of viral-infected circulating mononuclear cells. Figure 4 shows representative, nonisotopic detection of HIV nucleic acids in patient samples following coculture and by direct detection using freshly isolated mononuclear cells.

Peripheral blood monocytes, splenic mononuclear cells, bone marrow, and cells in culture infected by a sample of cerebrospinal fluid (CSF) were screened in a preliminary evaluation of direct testing of other cell types. One seropositive patient was found to have a single infected cell in a direct preparation of spleen cells. Coculture of this patient's blood mononuclear cells produced a culture with 100 infected cells per $10^{5}$ cells by day 14 of culture, increasing the confidence of the detection considerably. Stimulated T cells inoculated with CSF from a HIV-seropositive individual gave large numbers of virus-infected cells after 7 days. Several bone marrow samples were also investigated (isotopically); and positive cells were found in these patient samples as well, as were positive cells found in monocyte preparations isolated and cultured from seropositive donors. It is presumed that the in situ approach will also prove important for evaluation of cytologic aspects of the viral infection within tissue sections obtained by biopsy or autopsy. ${ }^{\mathbf{8 . 9} 21}$ While the work just described is currently anecdotal, it serves to illustrate further applications for this methodology.

Further increases in sensitivity and convenience will improve nonisotopic in situ hybridization; for instance, work in progress using a protocol developed for fluorescent detection of a single copy of viral $\mathrm{DNA}^{22}$ can detect a single copy of integrated HIV DNA. As an alternative or complement to other means of examination of patient samples such as dot blot, $^{17}$ antigen capture, ${ }^{18}$ or polymerase chain reaction (PCR), ${ }^{23-25}$ there are some immediate applications of the approach described in this work. One of the major contributions of in situ hybridization is the single-cell nature of the data, which allows a quantitative assessment of absolute numbers of cells containing viral nucleic acid. This allows a direct evaluation of viral load in the patient and can be used to test the effects of therapeutic drugs. If some patients are found to contain significant numbers of circulating infected lymphocytes, their response to therapy could be monitored using this approach (in vitro or in vivo). Second, the approach can be used, as shown above, to detect viruspositive cells in infants of seropositive mothers, where maternal antibodies may confuse the diagnosis; or in seronegative individuals to confirm suspected infection. ${ }^{26}$ Third, it provides a rapid, quantitative, and convenient complement to reverse transcriptase or $\mathrm{p} 24$ assays in conjunction with virus culture or serves as an alternative to culture in individuals with detectable, circulating infected cells. The time required to complete the assay directly on patient lymphocytes is less than 1 day and could be decreased considerably. Finally, it requires no specialized equipment other than a microscope, nor does it require specialized training.

\section{ACKNOWLEDGMENT}

We thank the personnel involved in handling live infectious virus: Frank Brewster, Lisa Marselle, and Maureen Layden. We appreciate the use of the HIV probe originally from Larry Lasky at Genentech and the help with filter blots by Jim Monroe. We would also like to thank Tom Sharpe, Barbara Young, and Carl Adler from Dupont Corporation and Jerry Ruth from Molecular Biosystems for their useful discussions and reagents for the SNAP probes and DuPont for help with the p24 assay in our laboratory (Fig 3). We thank Carel Mulder and Harriet Robinson for useful advice.

\section{REFERENCES}

1. Centers for Disease Control: Quarterly report to the Domestic Policy Council on the prevalence and rate of spread of HIV and AIDS-United States. MMWR 37:551, 1988

2. US Public Health Service: Coolfont Report: A PHS plan for prevention and control of AIDS and the AIDS virus. Public Health Rep 101:341, 1986

3. Fauci AS: The human immunodeficiency virus: Infectivity and mechanisms of pathogenesis. Science 239:617, 1988

4. Ward JW, Holmberg SD, Allen JR, Cohn DL, Critchley SE, Kleinman SH, Lenes BA, Ravenholt O, Davis JR, Quinn MG, Jaffe H: Transmission of human immunodeficiency virus (HIV) by blood transfusions screened as negative for HIV antibody. N Engl J Med 318:473, 1988

5. Scott GB, Buck BE, Letterman JG, Bloom FL, Parks WP: Acquired immunodeficiency syndrome in infants. $\mathbf{N}$ Engl $\mathbf{J}$ Med 310:76, 1984

6. Mayer KH, Stoddard AM, McCusker J, Ayotte D, Ferriani R, Groopman JE: Human T-lymphotropic virus type III in high-risk, antibody-negative homosexual men. Ann Intern Med 104:194, 1986
7. Farzadegan H, Polis MA, Wolinsky SM, Rinaldo CR Jr, Sninsky JJ, Kwok S, Griffith RL, Kaslow RA, Phair JP, Polk BF: Loss of human immunodeficiency virus type 1 (HIV-1) antibodies with evidence of viral infection in asymptomatic homosexual men. A report from the Multicenter AIDS Cohort Study. Ann Intern Med 108:785, 1988

8. Shaw GM, Harper ME, Hahn BH, Epstein LG, Gajdusek DC, Price RW, Navia BA. Petito CK, O'Hara CJ, Groopman JE: HTLV-III infection in brains of children and adults with AIDS encephalopathy. Science 227:177, 1985

9. Harper ME, Marselle LM, Gallo RC, Wong-Staal F: Detection of lymphocytes expressing human T-lymphotropic virus type III in lymph nodes and peripheral blood from infected individuals by in situ hybridization. Proc Natl Acad Sci USA 83:772, 1986

10. Busch MP, Rajagopalan MS, Gantz DM, Fu S, Steimer KS, Vyas GN: In situ hybridization and immunocytochemistry for improved assessment of human immunodeficiency virus cultures. Am J Clin Pathol 88:673, 1987

11. Lawrence JB, Singer RH: Quantitative analysis of in situ 
hybridization methods for the detection of actin gene expression. Nucleic Acids Res 13:1777, 1985

12. Shaw GM, Hahn BH, Arya SK, Groopman JE, Gallo RC, Wong-Staal F: Molecular characterization of human T-cell leukemia (lymphotropic) virus type III in the acquired immune deficiency syndrome. Science 226:1165, 1984

13. Langer PR, Waldrop AA, Ward DC: Enzymatic synthesis of biotin-labeled polynucleotides: Novel nucleic acid affinity probes. Proc Natl Acad Sci USA 78:6633, 1981

14. Singer RH, Lawrence JB, Villnave C: Optimization of in situ hybridization using isotopic and non-isotopic detection methods. BioTechniques 4:230, 1986

15. Unger ER, Budgeon LR, Myerson D, Brigati DJ: Viral diagnosis by in situ hybridization. Description of a rapid simplified colorimetric method. Am J Surg Pathol 10:1, 1986

16. Leary JJ, Brigati DJ, Ward DC: Rapid and colorimetric method for visualizing biotin-labelled DNA probes hybridized to DNA or RNA immobilized on nitrocellulose: Bio-blots. Proc Natl Acad Sci USA 80:4045, 1983

17. Monroe JE, Andrews C, Sullivan JL, Mulder C: Use of cytoplasmic dot-blot hybridization to detect human immunodeficiency virus RNA sequences in cultures of peripheral blood. J Infect Dis 155:320, 1987

18. Goudsmit J, de Wolf F, Paul DA, Epstein LG, Lange JM, Krone WJ, Speelman H, Wolters EC, Van der Noordaa J, Oleske JM: Expression of human immunodeficiency virus antigen (HIV$\mathrm{Ag}$ ) in serum and cerebrospinal fluid during acute and chronic infection. Lancet 2:177, 1986

19. Somasundaran M, Robinson HL: Unexpectedly high levels of
HIV-1 RNA and protein synthesis in a cytocidal infection. Science 242:1554, 1988

20. Brooks Jackson J, Sannerud KJ, Hopsicker JS, Kwok SY, Edson JR, Balfour HH: Hemophiliacs with HIV antibody are actively infected. JAMA 260:2236, 1988

21. Tenner-Racz K, Racz P, Schmidt H, Dietrich M, Kern P, Louie A, Gartner S, Popovic M: Immunohistochemical, electron microscopic and in situ hybridization evidence for the involvement of lymphatics in the spread of HIV-1. AIDS 2:299, 1988

22. Lawrence JB, Vilnave CA, Singer RH: Sensitive, highresolution chromatin and chromosome mapping in situ: Presence and orientation of two closely integrated copies of EBV in a lymphoma line. Cell 52:51, 1988

23. Kwok S, Mack DH, Mullis KB, Poiesz B, Ehrlich G, Blair D, Friedman-Kien A, Sninsky JJ. Identification of human immunodeficiency virus sequences by using in vitro enzymatic amplification and oligomer cleavage detection. J Virol 61:1690, 1987

24. Ou CY, Kwok S, Mitchell SW, Mack DH, Sninsky JJ, Krebs JW, Feorino P, Warfield D, Schochetman G: DNA amplification for direct detection of HIV-1 in DNA of peripheral blood mononuclear cells. Science 239:295, 1988

25. Hart C, Spira T, Moore J, Sninsky J, Schochetman G, Lifson A, Galphin J, Ou C: Direct detection of HIV RNA expression in seropositive subjects. Lancet 2:569, 1988

26. Imagawa DT, Lee MH, Wolinsky SM, Sano K, Morales F, Kwok S, Sninsky JJ, Nishanian PG, Giorgi J, Fahey JL, Dudley J, Visscher BR, Detels R: Human immunodeficiency virus type 1 infection in homosexual men who remain seronegative for prolonged periods. N Engl J Med 320:1458, 1989 